\title{
ICD-11 Revision of Mental Disorders: the Global Standard for Health Data, Clinical Documentation, and Statistical Aggregation
}

\author{
Классификация психических расстройств в МКБ-11: \\ единый стандарт для медицинской документации \\ и сбора статистических данных в здравоохранении \\ doi:10.17816/CP74
}

(C) Melita Vujnovic ${ }^{1}$, Olga Manukhina', Geoffrey M. Reed ${ }^{2}$, Pavlos N. Theodorakis', Konstantinos N. Fountoulakis ${ }^{3}$

${ }^{1}$ WHO Country Office in the Russian Federation

${ }^{2}$ Department of Psychiatry Columbia University Vagelos

College of Physicians and Surgeons, New York, NY, USA

${ }^{3} 3 \mathrm{rd}$ Department of Psychiatry, School of Medicine, Faculty

of Health Sciences, Aristotle University of Thessaloniki, Greece

\author{
(C) Мелита Вуйнович ${ }^{1}$, Ольга Манухина', \\ Джеффри М. Рид², Павлос Н. Теодоракис ${ }^{1}$, \\ Константинос Н. Фунтулакис ${ }^{3}$ \\ ${ }^{1}$ Страновой офис ВОЗ в Российской Федерации; \\ ${ }^{2}$ Кафедра психиатрии, Высшая медицинская школа \\ Валегоса, Колумбийский университет, Нью-Йорк, \\ uтат Нью-Йорк, США; ${ }^{3}$ З-я кафедра психиатрии, Школа \\ медицины, факультет медицинских наук, Университет \\ Аристотеля в Салониках, Греция
}

\begin{abstract}
Mental health conditions in the World Health Organization (WHO) European Region affect more than 10\% of the population, with 140,000 lives lost annually to suicide. Comorbidity with other diseases is high. However, basic mental health care is received by less than a third of patients. The COVID-19 pandemic has revealed the vulnerability of mental health services to disruptions and underscored the need to integrate mental health into response strategies. One of the flagship initiatives of the WHO European Programme of Work (EPW), 2020-2025: 'United Action for Better Health in Europe' is the establishment of a Mental Health Coalition at the European level. In this framework, reporting of health statistics using the International Classification of Diseases $11^{\text {th }}$ Revision (ICD-11) will begin on 1st January 2022. Clinical utility, scientific rigour and wider cultural applicability were all of prime importance in the development of the ICD-11. The 11th Revision was the end product of the most extensive global, multilingual, multidisciplinary and participative process ever undertaken for this task, involving more than 15,000 experts from 155 countries, representing approximately $80 \%$ of the world's population. With the adoption of the ICD-11 and the priority being given to mental health, new ideas based on the 30 years of research since the approval of the ICD-10 will be widely adopted and applied.
\end{abstract}

\section{АННОТАЦИЯ}

Психические расстройства в Европейском регионе Всемирной организации здравоохранения (ВОЗ) затрагивают более 10\% населения, при этом ежегодно в результате самоубийств погибает 140000 человек. Отмечается также высокая коморбидность с другими заболеваниями. Однако базовую психиатрическую помощь получают менее трети пациентов. Пандемия COVID-19 выявила уязвимость служб психиатрической помощи в сложившихся условиях и подчеркнула необходимость интеграции охраны психического здоровья в общие стратегии реагирования. Одна из флагманских инициатив Европейской программы работы ВОЗ (ЕПР) на 2020-2025 годы: «Совместные действия для улучшения здравоохранения в Европе» — это создание Коалиции 
по охране психического здоровья на европейском уровне. В этой связи представление статистических данных здравоохранения с использованием 11-й редакции Международной классификации болезней (МКБ-11) начнется 1 января 2022 года. Клиническая полезность, научная строгость и более широкая применимость с учетом культуральной специфики имели первостепенное значение при разработке МКБ-11. 11-я версия стала итогом самого масштабного глобального, многоязычного и мультидисциплинарного процесса пересмотра, когдалибо предпринимавшегося для решения подобной задачи, с участием более 15000 экспертов из 155 стран, что составляет примерно 80\% населения мира. С принятием МКБ-11 и повышением внимания к проблемам психического здоровья новые идеи, основанные на результатах исследований за последние 30 лет с момента утверждения МКБ-10, получат широкое распространение и применение.

Keywords: ICD-11; mental disorders; World Health Organization; Europe Ключевые слова: МКБ-11; психические расстройства; Всемирная организация здравоохранения; Европа

Even before the COVID-19 pandemic, the number of individuals with mental health conditions in the WHO European Region stood at over 110 million people, equivalent to more than $10 \%$ of the population. ${ }^{1,2}$ Moreover, 140,000 lives are lost each year in the Region to suicide, an unacceptably high figure that includes an increasing number of young people. ${ }^{3}$ Comorbidity with other non-communicable diseases (NCDs) ${ }^{4}$ and with communicable diseases such as tuberculosis ${ }^{5,6}$ and HIV $^{7}$ is frequent, with mental health conditions sharing many of the same risk factors. Yet, out of all those in the European Region with the most common mental health conditions - depression and anxiety - the proportion receiving even basic care and support is at best a third, and as low as $5-10 \%$ in some European countries., ${ }^{1,2}$

The COVID-19 pandemic has revealed to an even greater extent the vulnerability of public health systems to health emergencies, particularly related to disruptions to mental health services. It has underscored the need to integrate mental health into present and future preparedness and response strategies.

The WHO European Programme of Work (EPW), 2020-2025: «United Action for Better Health in Europe», adopted in Copenhagen last September at the 70th session of the WHO Regional Committee for Europe, consists of four flagship initiatives that complement its three core priorities. They are intended as accelerators of change, mobilizing around critical issues that feature prominently on the Member States' agendas. One of these four flagship initiatives is the establishment of a Mental Health Coalition at the European level. The upcoming World Health Assembly 2021 will devote considerable attention to mental health as a crucial part of a whole- of-society approach and universal health coverage, and to the WHO's capacity to strengthen its work on mental health at global, regional and country levels, through the updated Mental Health Global Action Plan for 2013-2030.

With the ICD-11 approval by the World Health Assembly in May 2019, after more than a decade of intensive work, the transition from ICD-10 to the new ICD-11 for all Member States of the WHO has officially begun. Member States will be able to begin reporting health statistics using the ICD-11 as a framework from $1^{\text {st }}$ January 2022.

The development of the ICD-11 chapter on Mental, Behavioural and Neurodevelopmental Disorders has been informed by several core principles, including clinical utility, international, transcultural and global applicability, and a multidisciplinary approach. ${ }^{8}$ Clinical utility was considered to be among the most important elements because it would determine the system's acceptance by practitioners and therefore influence its role in treatment design and various administrative and social functions, including pensions and legal determinations. ${ }^{9}$

The Clinical Descriptions and Diagnostic Guidelines (CDDG) for ICD-11 Mental, Behavioural and Neurodevelopmental Disorders has followed this same approach based on a strong scientific methodology. ${ }^{10,11}$ It demanded collaboration among hundreds of international experts in specific fields and extensive collaboration with WHO Member States, funding agencies and professional and scientific societies. This was the most extensive global, multilingual, multidisciplinary and participative process ever undertaken for the development or the revision of a classification system for mental disorders. 
It included more than 15,000 experts from 155 countries, representing approximately $80 \%$ of the world's population. ${ }^{12}$

Prime features of the development of the ICD-11 CDDG were: 1) the systematic gathering and distilling of data and information; 2) a lifespan approach rather than a cross-sectional conceptualization; 3) a focus on more pragmatic indices, including long-term comorbidity and disability. The sources and the final text of the Diagnostic and Statistical Manual of Mental Disorders, $5^{\text {th }}$ Edition (DSM-5) were also carefully reviewed. While there are considerable differences between the ICD-11 and the DSM-5, these are substantive and intentional rather than accidental, unnecessary or unsupported by data.

Comorbidity is considered to be one of the most problematic issues in modern classification systems along with the excess fragmentation of nosological entities, sometimes referred to as the 'atomization of psychopathology'. ${ }^{13,14}$ Some of the changes in the ICD-11 were made to decrease this artificial comorbidity, using broader categories like Bodily Distress Disorder and dimensional approaches, such as in Personality Disorder. A developmental approach to mental disorders has also unified the classification of child and adult presentations, with attention to presentations in older adults. This has facilitated the emphasis within the ICD-11 on a recovery-based viewpoint. Whereas the ICD-10 used a dichotomy between organic and nonorganic mental disorders, such a rigid conceptualization was avoided in the $11^{\text {th }}$ Revision.

A substantially new structure for the subclassification of mental disorders was followed (Table 1), which is also broadly compatible with the structure of the DSM-5. Regarding the disorders related to sexuality, paraphilic disorders (referred to as disorders of sexual preference in the ICD-10) were retained in the chapter on mental disorders. Sexual dysfunctions and gender incongruence (called Gender Identity Disorders in the ICD-10) were moved to a novel chapter specifically created for conditions related to sexual health. ${ }^{11,15}$

Several new nosological entities were created on the basis of data that had emerged since the approval of the ICD-10. Examples of such new entities are Bipolar II Disorder, Body Dysmorphic Disorder and Hoarding Disorder. Another unique characteristic is the adoption of a dimensional approach; in particular, it is notable that this was used not only for personality
Table 1. ICD-11 Chapter on mental, behavioural and neurodevelopmental disorders: disorder groupings

\begin{tabular}{|c|}
\hline Neurodevelopmental disorders \\
\hline Schizophrenia and other primary psychotic disorders \\
\hline Catatonia \\
\hline Mood disorders \\
\hline Anxiety and fear-related disorders \\
\hline Obsessive-compulsive and related disorders \\
\hline Disorders specifically associated with stress \\
\hline Dissociative disorders \\
\hline Feeding and eating disorders \\
\hline Elimination disorders \\
\hline Disorders of bodily distress and bodily experience \\
\hline Disorders due to substance use and addictive behaviours \\
\hline Impulse control disorders \\
\hline Disruptive behaviour and dissocial disorders \\
\hline Personality disorders \\
\hline Paraphilic disorders \\
\hline Factitious disorders \\
\hline Neurocognitive disorders \\
\hline $\begin{array}{l}\text { Mental and behavioural disorders associated with pregnancy, } \\
\text { childbirth and the puerperium }\end{array}$ \\
\hline $\begin{array}{l}\text { Psychological and behavioural factors affecting disorders or } \\
\text { diseases classified elsewhere }\end{array}$ \\
\hline $\begin{array}{l}\text { Secondary mental or behavioural syndromes associated with } \\
\text { disorders or diseases classified elsewhere }\end{array}$ \\
\hline
\end{tabular}

disorders but also for psychotic disorders. The extent to which this revolutionary change will be adopted by practitioners and its impact on reported data remain to be seen.

Cultural applicability ${ }^{16-18}$ was also of prime importance and therefore flexibility in clinical judgement was allowed, facilitating the incorporation and utilization of local knowledge when it can aid in clinical decisions.

The ICD-11 represents the first revision of the ICD for nearly 30 years and reflects both an unprecedented 
effort and advances in methodological quality. With the end product now in place, the most difficult phase, that of rigorous implementation should begin, with a focus on training and on adoption of the ICD-11 in training and educational curricula.

Authors contribution: Melita Vujnovic and Olga Manukhina conceptualized the paper and provided feedback on the manuscript; Konstantinos N. Fountoulakis and Pavlos N. Theodorakis drafted the first version of the manuscript; Geoffrey M. Reed revised and edited the manuscript. All authors approved the final version of the manuscript.

Funding: The research was carried out without additional funding.

Conflict of Interests: The authors report no conflicts of interest.

\section{Correspondence to:}

\section{Dr. Melita Vujnovic}

vujnovicm@who.int

\section{For citation:}

Vujnovic M, Manukhina O, Reed GM,

Pavlos N. Theodorakis PN, Fountoulakis KN. ICD-11 revision of mental disorders: the global standard for health data, clinical documentation, and statistical aggregation. Consortium Psychiatricum. 2021;2(2):3-6. doi:10.17816/CP74

\section{References}

1. Global Burden of Disease Study. Global health data exchange. Washington (DC): Institute for Health Metrics and Evaluation; 2016. Accessed April 24, 2021. http://ghdx.healthdata.org/gbdresults-tool

2. Data and resources: prevalence of mental health. In: Health topics. Copenhagen: WHO Regional Office for Europe; 2018. Accessed April 24, 2021. http://www.euro.who.int/en/healthtopics/noncommunicable-diseases/mental-health/ data-and-statistics

3. Global Health Observatory data repository. Geneva: World Health Organization; 2017. Accessed April 24, 2021. http://apps.who.int/ gho/data/node.home

4. Cohen A. Addressing comorbidity between mental disorders and major noncommunicable diseases. Copenhagen: WHO Regional Office for Europe; 2017. Accessed April 24, 2021. https://www. euro.who.int/en/publications/abstracts/addressing-comorbiditybetween-mental-disorders-and-major-noncommunicablediseases-2017
5. World Health Organization. Global Tuberculosis Report 2019. WHO; 2019.6. Doherty AM, Kelly J, McDonald C, O'Dywer AM, Keane J, Cooney J. A review of the interplay between tuberculosis and mental health. Gen Hosp Psychiatry. 2013;35(4):398-406. doi:10.1016/j. genhosppsych.2013.03.018

7. Uthman OA, Magidson JF, Safren SA, Nachega JB. Depression and adherence to antiretroviral therapy in low-, middle- and high-income countries: a systematic review and meta-analysis. Curr HIV/AIDS Rep. 2014;11(3):291-307. doi:10.1007/s11904-014-0220-1

8. International Advisory Group for the Revision of ICD-10 Mental and Behavioural Disorders. A conceptual framework for the revision of the ICD-10 classification of mental and behavioural disorders. World Psychiatry. 2011;10(2):86-92. doi:10.1002/j.2051-5545.2011.tb00022.x

9. Reed GM, Mendonca Correia J, Esparza P, et al. The WPAWHO Global Survey of Psychiatrists' Attitudes Towards Mental Disorders Classification. World Psychiatry. 2011;10(2):118-131. doi:10.1002/j.2051-5545.2011.tb00034.x

10. Clark LA, Cuthbert B, Lewis-Fernandez R, et al. Three Approaches to Understanding and Classifying Mental Disorder: ICD-11, DSM-5, and the National Institute of Mental Health's Research Domain Criteria (RDoC). Psychol Sci Public Interest. 2017;18(2):72-145. doi:10.1177/1529100617727266

11. Reed GM, First MB, Kogan CS, et al. Innovations and changes in the ICD-11 classification of mental, behavioural and neurodevelopmental disorders. World Psychiatry. 2019;18(1):3-19. doi:10.1002/wps.20611

12. First MB, Reed GM, Hyman SE, Saxena S. The development of the ICD-11 Clinical Descriptions and Diagnostic Guidelines for Mental and Behavioural Disorders. World Psychiatry. 2015;14(1):82-90. doi:10.1002/wps.20189

13. Parnas J, Sass LA, Zahavi D. Recent developments in philosophy of psychopathology. Curr Opin Psychiatry. 2008;21(6):578-584. doi:10.1097/yco.0b013e32830e4610

14. Potter NN. Recent developments in philosophy of mind and psychopathology. Curr Opin Psychiatry. 2010;23(6):542-545. doi:10.1097/YCO.0b013e32833d41ed

15. Reed GM, Drescher J, Krueger RB, et al. Disorders related to sexuality and gender identity in the ICD-11: revising the ICD-10 classification based on current scientific evidence, best clinical practices, and human rights considerations. World Psychiatry. 2016;15(3):205-221. doi:10.1002/wps.20354

16. Kleinman A. Rethinking psychiatry: from cultural category to personal experience. Free Press; 1991.

17. Littlewood R. Psychiatry's Culture. International Journal of Social Psychiatry. 2016;42(4):245-268. doi:10.1177/002076409604200402

18. Sadler J. Values in psychiatric diagnosis and classification. In: Fulford KW, Davies M, Gipps R, et al. The Oxford handbook of philosophy and psychiatry. Oxford University Press; 2013 